\title{
Pleiotropic Effects of gri on Seed Coat and Flower Color in Common Bean
}

\author{
Mark J. Bassett ${ }^{1}$ \\ Vegetable Crops Department, Institute of Food and Agricultural \\ Sciences, University of Florida, Gainesville, FL 32611 \\ Additional index words. Phaseolus vulgaris
}

Abstract. The effects of gri on seed coat and flower color were investigated in a study using Lamprecht line V0400 (PI 527735) as the known source of gri. Seed and flower color data were taken on observations of $\mathrm{F}_{2}, \mathrm{BC}_{1}-\mathrm{F}_{2}$, and $\mathrm{BC}_{2},-\mathrm{F}_{2}$ populations from crosses of V0400 with the recurrent parent S-593. Segregation was observed for a unique flower color pattern: wing petals have a very pale tinge of blue (laelia), and the banner petal has two violet dots $(\approx 3-$ to $4-\mathrm{mm}$ diameter $)$ on a nearly white background. This very pale laelia flower color cosegregates with gray-white seed coats produced by gri. Furthermore, the very pale laelia color depends on the action of $V$ for expression and is extinguished by $v$, which produces pure white flowers. Thus, it was demonstrated that the very pale laelia flower color, for which Lamprecht tentatively proposed the gene symbol $\mathrm{v}^{\text {pal }}$, is not controlled by an allele at $V$ but is a pleiotropic effect of gri. It was also demonstrated that Lamprecht line V0060 (PI 527717) carries $v^{\text {lae }}$, not $v$, as indicated by the genotypic notes accompanying the Lamprecht seed collection.

The gri (griseoalbus) gene is one of two basic seed-coat color factors (Lamprecht, 1936) in common bean (Phaseolus vulgaris L.), the other basic color gene being $p$ (Emerson, 1909). Griseoalbus means graywhite, referring to the action of gri on seed coat color, where whatever seed-coat would express with Gri is reduced to gray-white by the action of gri. The paper of Lamprecht (1936) is the only report I found of experimental work with gri. When Prakken (1970) published his critical review of all previous work with the genetics of seed coat color, he dismissed gri with the statement that he had no personal experience with this gene.

Received for publication 22 Oct. 1990. Accepted for publication 17 Oct. 1991. Fla. Agr. Expt. Sta. Journal Series no. R-01090. The cost of publishing this paper was defrayed in part by the payment of page charges. Under postal regulations, this paper therefore must be hereby marked advertisement solely to indicate this fact.

${ }^{1}$ Professor of Horticulture.
Because the treatise by Prakken (1970) is generally regarded as the most authoritative and most comprehensive treatment of seedcoat genetics, there is some danger that future researchers will regard Lamprecht's (1936) report as unimportant or of dubious competence. Fortunately, the review and commentary by Leakey (1988) on the marker genes of common bean treated gri as a credible seed-coat marker and speculated that this locus probably operates "at a later biosynthetic step than $p$ while still preventing the formation of both flavonol and anthocyanin pigments."

Lamprecht (1936) not only discovered the gri locus but also a new flower color not previously reported, which he called very pale laelia (sehr blass Laelia Farbig). This hue is distinctly more pale than the light laelia of $\mathrm{v}^{\text {lae }}$. Lamprecht tentatively assigned the symbol $\mathrm{v}^{\mathrm{pal}}$ (pallidiflorus) to the new gene and further speculated that it occupied the following position in an allelic dominance series: $V>v^{\text {lae }}>v^{\text {pal }}>\mathrm{v}$. The purpose of this paper is to investigate the effects of gri on flower and seed coat by backcrossing gri into a recurrent parent with $V$.

Line 5-593 has shiny black seeds and has the genotype $P$ Gri $C D J G B V$ (Prakken, 1970; M.J. B., unpublished data). The source of gri chosen for this project was Lamprecht line V0400, now PI 527735, which has the genotype $P$ gri $c r j g b v$, according to the seed collection genotypic notes (Lamprecht, transcribed by S. Blixt). V0400 has white flowers (due to $v$ ) and white seed coat (due to gri $c$ j), according to Lamprecht (1936). The cross 5-593 $\times$ V0400 was made and the $\mathrm{F}_{2}$ was planted in the field in 1987 in plot 7-489. The plants were classified for flower color. Plants with white or pale color flowers (the putative phenotype of gri) were tagged. Seed samples from the tagged plants were classified for color.

Several selections were made among white flower and pale color flower segregants in 7-489. Two single plants in the $\mathrm{F}_{4}$ were backcrossed to 5-593: 7-489 $\mathrm{F}_{4} \# 1$ with white flowers and gray-white seed (gri v) and 7$489 \mathrm{~F}_{4} \# 3$ with pale color flowers and graywhite seed (gri v). The $\mathrm{F}_{2}$ seed were planted in the field in 1989 in plots 9-369 and 370 for 5-593 × 7-489 $\mathrm{F}_{4} \# 1$ and plot 9-371 for $5-593 \times 7-489 \mathrm{~F}_{4} \# 3$. The plants were classified for flower color, and a sample of plants from each cross was tagged (96 plants from the cross with $7-489 \mathrm{~F}_{4} \# 1$ and 48 plants from the cross with 7-489 $\mathrm{F}_{4} \# 3$ ). Seed samples from the tagged plants were classified for color.

A selection was made for an $\mathrm{F}_{2}$ plant in plot 9-371 that segregated for pale flower (with strong banner dots) and gray-white seed. $\mathrm{An}_{3}$ progeny plant of this selection was backcrossed $\left(\mathrm{BC}_{2}\right)$ to 5-593. The $\mathrm{BC}_{2}-\mathrm{F}_{2}$ progeny were planted in the field in 1990 in separate plots for each $\mathrm{BC}_{2}-\mathrm{F}_{1}$ plant, and only one plot was classified for flower color and seed color.

A cross was made between Lamprecht line V0060 (PI 527717) and a genetic tester stock $v \mathrm{BC}_{2} 5-593$ to investigate the genotype of V0060 at the Gri and V loci. Notes were 
Table 1. Segregation for seed coat and flower color in the $F_{2}$ of the cross 5-593 Gri V $\times$ V0400 gri $v$.

\begin{tabular}{|c|c|c|c|c|}
\hline \multicolumn{3}{|c|}{ Phenotypic classes } & tontester & \\
\hline \multirow[b]{2}{*}{$\begin{array}{l}\text { Colored } \\
\text { flowery }\end{array}$} & \multicolumn{2}{|c|}{ White or pale ${ }^{z}$ color flower } & & \\
\hline & $\begin{array}{c}\text { Brown or } \\
\text { white }^{x} \text { seed }\end{array}$ & $\begin{array}{c}\text { Gray-white } \\
\text { seed }\end{array}$ & $\begin{array}{c}x^{2} \\
(9: 3: 4)\end{array}$ & $P$ \\
\hline 83 & 18 & 30 & 3.161 & 0.08 \\
\hline
\end{tabular}

${ }^{2}$ Pale flowers have a faint tint of violet in wing petals and two dots of violet on banner.

ySegragated for biships violet and cobalt violet flower colors; seed colors not classified.

xNo satisfactory model was found that included the white seed class.

Table 2. Segregation for flower and seed coat colors in $\mathrm{F}_{2}$ from the cross $5-593 \mathrm{Gri} V \times 7-489 \mathrm{~F}_{4} \# 1$ gri $v$ (white flower and gray-white seed).

\begin{tabular}{ccccc}
\hline \hline & Phenotypic classes & & & \\
\hline $\begin{array}{l}\text { Colored } \\
\text { flowers and seed }\end{array}$ & $\begin{array}{l}\text { Pale flowery and } \\
\text { gray-white seed }\end{array}$ & $\begin{array}{l}\text { White flower and } \\
\text { colored or gray- } \\
\text { white seed }\end{array}$ & $\begin{array}{c}\chi^{2} \\
(9: 3: 4)\end{array}$ & $P$ \\
\hline 400 & 117 & 156 & 2.775 & 0.25 \\
\hline
\end{tabular}

${ }^{2}$ Bishops violet $(V / V)$ or cobalt violet $(V / v)$ flowers and no segregation for gray-white seed (only Gri/-segregants).

'Faint tint of violet in wing petals and two dots of violet on banner petal ( $\mathrm{gri} \mathrm{V}$ ).

${ }^{\times} A$ sample of this flower color class was classified for seed color and segregated 13 colored : 5 graywhite seed, giving $\chi^{2}(3: 1)=0.074, P=0.79$.

Table 3. Segregation for flower and seed coat colors in the $\mathrm{F}_{2}$ from the cross $5-593 \mathrm{Gri} V \times 7-489 \mathrm{~F}_{4}$ \#3 gri $V$ (pale color ${ }^{2}$ flower and gray-white seed).

\begin{tabular}{lcccccc}
\hline \hline & Phenotypic classes & & & & \\
$\begin{array}{l}\text { Bishops violet } \\
\text { flowers and } \\
\text { colored seed }\end{array}$ & $\begin{array}{c}\text { Pale color } \\
\text { flowers and } \\
\text { gray-white seed }\end{array}$ & $\begin{array}{c}\text { Pure white } \\
\text { flowers, }\end{array}$ & & $\begin{array}{c}\chi^{2} \\
\text { Ratio } \\
\text { tested }\end{array}$ & Value & $\chi^{2}$ \\
\hline \multicolumn{1}{c}{240} & 62 & 5 & $48: 15: 1$ & 1.797 & 0.41 \\
\hline
\end{tabular}

${ }^{\mathrm{z}}$ Faint tint of violet in wing petals and two dots of violet on banner petal.

YThe pale color and pure white flower classes were combined for a $\chi^{2}(3: 1)$ test of 240 and $67\left(\chi^{2}=\right.$ $1.65, P=0.20)$.

${ }^{\times}$Seed color was classified on only one plant (gray-white seed) in this class.

taken on flower and seed color in the $\mathrm{F}_{1}$ and $\mathrm{F}_{2}$ progeny.

The cross $5-593 \times$ V0400 segregated in $F_{2}$ for four flower colors (Table 1). The colors bishops violet, cobalt violet, and white were already known to be the expression of $V / V$ $V / v$, and $v / v$, respectively, from previous work (Bassett et al., 1990). The pale color flowers were new to my experience. The wing petals had only a faint tint of violet, whereas the banner petal had two dots $(\approx 3-$ to 4 -mm diameter) of much stronger violet, one on each side of the midline vertical suture. Among the pale flower color segregants there was a striking variability in the intensity of the flower color from plant to plant, raising the question of whether this was due to inherent instability of this character or to segregation of other background genes with small effects on intensity of coloration. A sample of the plants with either pale flowers or white flowers was classified for seed color. The pale flower selections segregated for 23 gray-white and two with pure white seed; whereas the selections with pure white flowers segregated for 15 with brown seed, seven with gray-white seed, and one with pure white seed. To simplify the analysis, the seeds from pale color and pure white flower plants were combined and then separated into either graywhite or other colors (Table 1). An acceptable fit was found for a two-factor ratio 9:3:4 with the hypothesis that gri and $v$ are the two genes (Table 1). In this model, colored flowers have Gri/- V/- (9/16), pale flowers have gri V/- (3/16), and white flowers have Gri/$v$ and gri $v(4 / 16)$. It is clear that plants with pale flowers due to gri have either gray-white seed or pure white seed (due to gri $C d j$ ). Plants with pure white flowers due to v) usually have mineral-brown seed (the pleiotropic effect of $v$ ), but they can also segregate for gri (reduces brown to gray-white) or gri and other genes (producing pure white seed). It is not the intention of this paper to confirm or further investigate the genetics of these pure white seeds but only to investigate whether a correlation exists between gri and the pale flower color.

The $\mathrm{BC}_{1}-\mathrm{F}_{2}$ from the cross $5-593 \times 7-489$ $\mathrm{F}_{4} \# 1$ (with white flowers and gray-white seed) segregated for the same four flower colors as did the $\mathrm{F}_{2}$ from 5-593 $\times \mathrm{V0400}$ (Table 2). All 19 of the pale flower plants sampled had gray-white seed, whereas the white flower plants sampled segregated in a 3 colored : 1 gray-white ratio for seeds (Table 2). Also the segregation for the three flower color classes-colored (bishops violet and cobalt violet), pale color, and pure white-gave a good fit to a 9:3:4 ratio, respectively. It is clear that segregation for the $\mathrm{v}$ allele blocks the expression of flower color in the gri segregants, which still express the gray-white seed color.

The parent 7-489 $\mathrm{F}_{4} \# 3$ (pale color flower and gray-white seed) was chosen because it is free of the $\mathrm{v}$ allele. The $\mathrm{BC}_{1}-\mathrm{F}_{2}$ from the cross 5-593 $\times$ 7-489 $\mathrm{F}_{4} \# 3$ segregated for only three flower colors: bishops violet, pale color, and a small percentage of pure white (Table 3 ). If one combines the pale color and pure white classes into a reduced color class, one obtains a good fit to a 3 colored : 1 reduced color ratio, respectively. The fact that a single factor ratio fits and no cobalt violet segregants were observed indicates that no segregation occurred at the $V$ locus. Among the 38 bishops violet flowered plants sampled there were no gray-white seed segregants, whereas all nine pale flowered plants sampled had gray-white seeds. Only one pure white flower plant was sampled, and it had gray-white seed. A good fit was obtained for a 48:15:1 ratio for the three flower color classes (Table 3). It may be that gri and two other recessive genes can block the expression of flower color.

The cross 9-371 $\mathrm{F}_{3}$ (with strong banner dots) $\times 5-593$ produced the $\mathrm{BC}_{2}-\mathrm{F}_{1}$ to 5-593 . Three plants of this cross were grown and their progeny planted in separate plots, 0$550,0-551$, and $0-552$. The flowers in all three $\mathrm{BC}_{2}-\mathrm{F}_{2}$ plots were examined and found to be segregating for only two color types: either bishops violet or the strongly colored gri color pattern, viz., a banner petal with a strong violet dot on either side of the vertical suture and a pale tinge of violet in the wing petals. All plants with pale flowers were tagged. Seeds were harvested from only one plot, 0-550. There were only two segregation classes: 39 plants with bishops violet flowers and pure black seeds and 10 plants with pale flowers and gray white seeds. A 3:1 ratio was tested on the observed values, 39 and 10, respectively, giving a good fit $\left(\mathrm{x}^{2}=0.551, P=0.46\right)$. The absence of independent segregation for flower and seed color demonstrates that the gri allele has pleiotropic effects in the presence of $V$, viz., reducing black testa color to gray-white and reducing bishops violet flower color to the pale color pattern described above. Thus, it is clear that the segregants for very pale laelia flower color are not due to a new allele, $\mathrm{v}^{\text {pal }}$, at the $V$ locus as Lamprecht (1936) had speculated, but are due to a pleiotropic effect of gri in the presence of $V$.

The intensity of the violet color in the dots on the banner petals was uniformly strong in all $\mathrm{BC}_{2}-\mathrm{F}_{2}$ segregants with gri. Similarly, the seed coats were uniformly dark gray-white in all gri segregants. From this result it can be inferred that there is no inherent instability of color intensity expression derived from gri. The great variability of intensity of violet in flowers of gri segregants in the $\mathrm{F}_{2}$ of $5-593 \times \mathrm{V} 0400$ and the $\mathrm{F}_{2}$ from the $\mathrm{BC}_{1}$ of gri to 5-593 is the result of segregation of background genes, e.g., $c, j, g$, and $b$. The intensity of the gray in the gray-white seed coats and that of the violet in the pale flowers of gri segregants are pleiotropically controlled by the same background genotypes. For example, if a genotype darkens the gray in gray-white seed coats, it also darkens the violet in the corolla; and similarly, if a geno- 
type lightens the gray in a gray-white seed coat, it lightens the violet in the corolla. Once the genetic background has all dominant alleles at the C J G B V loci due to backcrossing to 5-593 with strong selection for dark color, then all gri segregants have uniformly dark gray-white seed coats and strong violet banner petal dots.

The investigation by Lamprecht (1936) studied two crosses, \#145 involving line V0059 $\times$ line 146, and \#162 involving line V0060 $\times$ line 146 . The genotypes of the lines were as follows: V0059 was $P$ gri $C r$ ins $J$ $G b v$, V0060 was $P$ gri $C r$ Ins $J g b v$, and line 146 was $P$ Gri $c$ r ins j $g$ b v. According to Prakken (1970), Lamprecht's Ins is the equivalent of $D$, the hilum ring factor. The phenotypes of the lines V0059 and V0060 were very pale laelia flowers and gray-white seed coats, whereas line 124 had white flow- ers and seed coats. I hypothesize that $\nu^{\text {pal }}$ does not exist and that the very pale laelia flower color is a pleiotropic effect of gri. Furthermore, gri genotypes express the very pale laelia color in the presence of $V$ but not $\mathrm{v}$. If the hypothesis is correct, then it refutes the proposition that lines V0059 and V0060 express very pale laelia in the presence of gri $v$ as Lamprecht stated. My cross involving $\mathrm{V} 0060 \mathrm{x} v \mathrm{BC}_{2} 5-593$ gave $\mathrm{F}_{1}$ progeny with the pale flower color (pastel lavender) characteristic for the $v / v$ ia interaction, and not the white flower color produced by $v / v$. The $\mathrm{F}_{2}$ progeny segregated for white flowers and all the pale colors ranging from the rose purple associated with $\mathrm{v}{ }^{\mathrm{ke}}$ to the more delicate hues produced by $v / v^{\text {lae }}$, gri $v^{\text {lae }}$, and gri $v^{\text {lae }} / \nu$. It is clear that V0060 carries $v^{\text {lae }}$ and not $\mathrm{v}$. The same is very likely true for V0059, which is identical to V0060 in appearance.

\section{Literature Cited}

Bassett, M.J., L.B. Xue, and L.C. Hannah. 1990. Flower colors in common bean produced by interactions of the Sal and $V$ loci and a gametophyte factor $G a$ linked to Sal. J. Amer. Soc. Hort. Sci. 115:1029-1033.

Emerson, R.A. 1909. Factors for mottling in beans. Amer. Breed. Assn. 5:368-376.

Lamprecht, H. 1936. Zur Genetik von Phaseolus vulgaris. XIII. Ein neues Grundgen für Testafarben, ein weiteres Testafarbgen sowie etwas über Blütenfarben. Hereditas 22:241-268.

Leakey, C.L.A. 1988. Genotypic and phenotypic markers in common bean, p. 245-327. In: P. Gepts (ed.). Genetic resources of Phaseolus beans. Kluwer Academic, Boston.

Prakken, R. 1970. Inheritance of colour in Phaseolus vulgaris L. II. A critical review. Meded. Landbouwhogeschool Wageningen 70-23:1-38. 